Relations industrielles

Industrial Relations

\title{
Jairus Banaji and Rahini Hensman, Beyond Multinationalism: Management Policy and Bargaining Relationship in International Companies
}

\section{Hem C. Jain}

Volume 46, numéro 4, 1991

URI : https://id.erudit.org/iderudit/050730ar

DOI : https://doi.org/10.7202/050730ar

Aller au sommaire du numéro

Éditeur(s)

Département des relations industrielles de l'Université Laval

ISSN

0034-379X (imprimé)

1703-8138 (numérique)

Découvrir la revue

Citer ce compte rendu

Jain, H. C. (1991). Compte rendu de [Jairus Banaji and Rahini Hensman, Beyond Multinationalism: Management Policy and Bargaining Relationship in International Companies]. Relations industrielles / Industrial Relations, 46(4), 874-875. https://doi.org/10.7202/050730ar

Tous droits réservés @ C Département des relations industrielles de l'Université Laval, 1991
Ce document est protégé par la loi sur le droit d'auteur. L'utilisation des services d'Érudit (y compris la reproduction) est assujettie à sa politique d'utilisation que vous pouvez consulter en ligne.

https://apropos.erudit.org/fr/usagers/politique-dutilisation/ 
Third, the authors could have done more in drawing out the implications for practitioners. What are the characteristics necessary to maximize likelihood of successful implementation? When should either profit sharing, employee ownership, or neither, be used? Fourth, the presentation is very dry, and so much data is presented that the reader tends to get bogged down in the details, losing the overall picture. The books are tough reading. Limiting the presentation of data to the key findings would have improved readability. Perhaps the other findings could have been placed in an appendix. Finally, the proofreading could have been improved. For example, the headings on many of the tables in the second book are incorrect.

These limitations should not, however, be allowed to detract from the fact that this study does constitute a major accomplishment, and a major advancement to our knowledge on PS/EO. Although the lay reader will find these books rather inaccessible, they are essential reading for those scholars and policy makers who work with profit sharing and employee ownership.

Richard J. LoNG

University of Saskatchewan

Beyond Multinationalism: Management Policy and Bargaining Relationship in International Companies, by Jairus Banaji and Rahini Hensman, New Delhi, Sage Publications, 1990, 224 p., ISBN 81-7036-182-6 (India)

This book is about employer-employee relations in two multinational companies, i.e. Unilever and Phillips. These two Dutch multinationals have considerable manufacturing investment in India. The book is a comparative study of transnational differences in structure, level of earnings, leave, working hours, conditions of work, management attitude towards union and rate of conflict in India and Holland.

The basic premise of the book is that multinationals are not bad in the sense that they hold back the economic development of the host country. The authors argue that "mobile international firms integrate production facilities across national boundaries and whose presence is an inexorable part of growth of social labour as world labour".

One of the major problems in the foreign subsidiaries of the multinational is that Head Office retains control over all major decision making powers in the areas of manufacturing, finance, capital investment and marketing of products. Labour relations is decentralized because of local customs and regard for the autonomy of local management.

Industrial restructuring in Dutch multinationals emerged in response to the increased competition. Restructuring involved stream lining operations by selling off peripheral activities such as transport, petrochemical and coca products for Unilever. The Dutch electric company Phillips designed a pilot plan for its foreign subsidiaries, which is small and less automated, to accommodate smaller markets and higher employment.

As far as the bargaining system in Holland and India is concerned, there is lack of formal bargaining rights at the plant level in Dutch industry, but in India the local union plays an important role in day-to-day bargaining. Workers in Bombay have much greater control over the bargaining process than their counterparts working for the same companies in Holland. 
However, authors fail to point out the major problems the bargaining system faces in India; that unions in India are highly politicized and union leaders are mostly the outsiders, who are power hungry. There is a great deal of rivalry among unions and there are too many unions in a company in India. In Bombay, majority of plants are massively conflict prone. Unions often engage in slow-down tactics, i.e. in artificial restricting of output, whenever they want their demands to be met. Many employers are afraid of the power of unions.

While in Holland there is an extremely low level of pay dispersion, which indicates tight centralization of pay levels imposed by Phillip. In Bombay on the other hand, pay scales at two multinationals are determined by comparing the average total pay across the whole Bombay labour market regardless of their specific type of production or industrial classification.

As far as working hours and labour use is concerned there still remains areas of substantial inequality, i.e. considerably shorter working hours and longer sick leave in Holland than in Bombay. There are also major differences in overall management attitudes toward unions in India and Holland. The Phillips Company in Holland restricts bargaining with unions mostly to the issues of financial nature while in Bombay the management at Phillips Kalwa does negotiate with the unions, but does not always abide by the agreements.

In short, this study provides a detailed comparison of employment conditions and labour relations in the European and Indian plants of the same companies. The Headquarters of multinationals keep a tight control over decisions concerning restructuring and investment and isolate them from collective bargaining.

The book is easy to read and written in an interesting style. It is most thoroughly researched and serves as a useful guide to those interested in labour relations in international companies located in India and Holland.

Hem C. JAIN

University of New Brunswick

Les organisations: une approche systémique, par Yves Bertrand et Patrick Guillemet, les Éditions Agence d'Arc Inc., Chotard et associés, éds et Télé-Université, 1989, 333 p., ISBN 2-89022-164-4 (Les éditions Agence d'Arc Inc.)

Pendant longtemps, et suite aux enseignements de l'École de relations humaines, nous étions incités à définir les organisations sociales en retenant surtout et presque exclusivement les personnes et les rôles. Nous faisions alors des organisations «un regroupement d'individus accomplissant des tâches différenciées et coordonnées par la présence d'une hiérarchie en vue de réaliser un ou des objectifs communs». Dans ce présent ouvrage, qui sert de document de base pour un cours offert par Télé-université, les auteurs optent plutôt pour une conception beaucoup plus large des organisations en privilégiant l'approche systémique qui colle de près à l'analogie organiciste: cette tendance à comparer les organisations à des organismes vivants cherchant à survivre dans un environnement plutôt hostile. L'organisation devient donc pour ces deux auteurs «un système situé dans un environnement comprenant un sous-système culturel (des buts, fins, valeurs, croyances), un sous-système technoproductif (des connaissances, des technologies, de l'expérience), un sous-système structurel (une division formelle et informelle du travail), un sous-système psychosocial (des gens ayant des relations entre eux) 